\section{ПРОКУРОРСКИЙ НАДЗОР В СИСТЕМЕ ПРОЦЕССУАЛЬНЫХ ГАРАНТИЙ ПРАВ УЧАСТНИКОВ УГОЛОВНОГО ПРОЦЕССА}

\section{PROSECUTORS SUPERVISION IN THE SYSTEM OF PROCEDURAL PROTECTION OF RIGHTS OF CRIMINAL TRIAL PARTICIPANTS}

Аннотация:

В статье рассматривается роль прокурорского надзора в системе гарантий прав участников уголовного процесса. В результате анализа автором сделан вывод о необходимости внесения изменений в уголовно-процессуальное законодательство в целях оптимизации надзорных полномочий прокурора.

Ключевые слова:

заключение под стражу, меры пресечения, полномочия прокурора, преступление, прокурорский надзор, уголовное преследование, участники уголовного судопроизводства.
Summary: sion in the system of protection of rights of criminal process participants. As a result of the analysis, the author concludes that there is a need for amending the criminal procedure law in order to improve the supervision powers of the prosecutor.

Keywords:

detention, pre-trial restrictions, prosecutor's powers, crime, public prosecutor's supervision, prosecution, participants in criminal proceedings.
The article discusses the role of prosecutorial supervi-

Высокий уровень преступности в стране, неустойчивая законодательная практика, экономическая и социальная незащищенность граждан, правовой нигилизм населения часто препятствуют нормальному ходу судопроизводства. Это вынуждает некоторых представителей правоохранительных органов пренебрегать регламентированными процедурами в ходе расследования уголовных дел. В связи с этим политика власти направлена на обеспечение доступа граждан к правосудию, гарантирующего всем участникам уголовного судопроизводства надежную систему реализации принадлежащих им прав с одновременным наложением соответствующих обязанностей на органы, задействованные в уголовном процессе. Деятельность последних при этом подлежит строгой законодательной регламентации и контролю со стороны государства. Только при таких условиях возможны ограждение личности от необоснованного принудительного воздействия и выполнение задач уголовного судопроизводства.

Одним из видов контрольно-надзорной деятельности, направленной на обеспечение процессуальных гарантий прав участников уголовного процесса, является прокурорский надзор. Он имеет преимущества перед ведомственным и судебным контролем. Во-первых, у прокурорского надзора отсутствуют ведомственные интересы, во-вторых, он характеризуется оперативностью. В отличие от судебного контроля прокурорский надзор включает в себя правомочие прокурора по собственной инициативе проверять законность и обоснованность обеспечения процессуальных гарантий прав участников уголовного судопроизводства. Однако действенность прокурорского надзора нуждается в совершенствовании.

Как подтверждают анализ уголовно-процессуального законодательства РФ и выводы по научным разработкам, прокурорский надзор - это особый вид деятельности, регламентированный государством, занимающий особое место в системе гарантий прав и свобод гражданина [1, с. 159].

Прокурорский надзор за соблюдением прав участников уголовного процесса определяется его назначением. Последнее раскрывается как защита прав и законных интересов физических лиц и организаций, которые стали жертвами преступных деяний, а также личности от ограничения ее прав и свобод, необоснованного обвинения и пр. (ст. 6 УПК РФ) [2].

Прокурорский надзор в системе обеспечения процессуальных гарантий прав участников уголовного процесса призван гарантировать, с одной стороны, достижение интересов правосудия, а с другой - охрану и защиту прав, законных интересов личности. Наблюдается некое противоречие. Данное обстоятельство и обусловливает проблемный характер рассматриваемой темы.

Обращаясь к механизму обеспечения процессуальных гарантий, отметим, что гарантии прав и законных интересов лиц, вступающих в уголовно-процессуальные правоотношения с органами, ведущими уголовный процесс, реализуются законом через наделение личности субъективными правами и организацию условий, возможностей для их осуществления в конкретных 
процессуальных ситуациях. В то же время данные гарантии обеспечиваются возложением законом на органы и должностных лиц обязанностей, корреспондирующих с соответствующими правами личности.

На орган, ведущий уголовный процесс, при обретении лицом соответствующего статуса, принятии решения, совершении того или иного действия в каждом случае возложена обязанность разъяснять указанному лицу его права. Недопустимо формальное выполнение данного требования закона. В связи с этим необходим действенный контроль со стороны органов прокуратуры.

Прокурорский надзор за обеспечением процессуальных гарантий прав участников уголовного процесса, на наш взгляд, может быть двух видов: активным и пассивным. Выделение данных видов надзора обусловлено наличием инициативы (активностью) или ее отсутствием (пассивностью) в начале прокурорской проверки, а также принятием итогового решения по жалобе или ходатайству. Помимо этого, активная форма участия подразумевает возможность такой проверки по собственной инициативе прокурора, пассивная - его участие в проверке, предпринятой иным органом (т. е. не прокурором). От того, какой из перечисленных видов прокурорского надзора применяется, зависят его содержательная сторона и специфика правового статуса, полномочий, влияющих на безопасность и меры государственной защиты в отношении защищаемых лиц.

Ряд норм действующего УПК РФ устанавливает достаточные процессуальные правомочия прокурора при производстве по уголовному делу. На наш взгляд, они предоставляют ему право на проверку законности и обоснованности действий государственных органов при реализации гарантий прав участников уголовного процесса.

Так, согласно п. 3 ч. 2 ст. 37 УПК РФ прокурор наделен правом «требовать от органов дознания и следственных органов устранения нарушений федерального законодательства, допущенных в ходе дознания или предварительного следствия». Например, прокурор может настаивать на устранении нарушения, заключающегося в неразъяснении участнику процесса его права на адвоката, а также на предоставлении бесплатного защитника. При отсутствии жалобы со стороны участника прокурор может инициировать проверку законности и обоснованности принятия решения об отказе в назначении бесплатного защитника: «По мотивированному письменному запросу прокурора ему предоставляется возможность ознакомиться с материалами находящегося в производстве уголовного дела». Это позволяет прокурору постоянно контролировать надлежащее исполнение действующего уголовно-процессуального и иного законодательства ведущими производство по делу должностными лицами и органами.

Возможность активного участия прокурора в восстановлении нарушенного права участника уголовного процесса выражается и в форме его обращения к руководству, что установлено в ч. 6 ст. 37 УПК РФ: «В случае несогласия руководителя следственного органа либо следователя с требованиями прокурора об устранении нарушений федерального законодательства, допущенных в ходе предварительного следствия, прокурор вправе обратиться с требованием об устранении указанных нарушений к руководителю вышестоящего следственного органа, вплоть до обращения к Генеральному прокурору Российской Федерации, решение которого является окончательным». Отметим, что содержание ст. 37 подвергалось справедливой критике ученых в части необходимости ее детализации и конкретизации полномочий прокурора по надзору за предварительным следствием. Это важно также в связи с тем, что наука в области уголовно-процессуального права отмечает связь усложнения процессуальной формы с увеличением гарантий прав и законных интересов участников уголовного процесса.

Пассивное (опосредованное) участие прокурора может выражаться в проверке жалоб и ходатайств от участников процесса на принятые решения, действия или бездействие ведущего производство по делу должностного лица в порядке ст. 124 и 125 УПК РФ.

Прокурорский надзор в системе процессуальных гарантий прав участников уголовного процесса наиболее значим при возбуждении уголовного дела. При этом к числу гарантий прав относятся следующие:

- строго определенный уголовно-процессуальным законом круг органов и должностных лиц, правомочных принимать решения о начале уголовного преследования или отказе в возбуждении уголовного дела (органы дознания, начальник следственного отдела, следователь, дознаватель, прокурор);

- законодательная регламентация процедуры прохождения заявления или сообщения о преступлениях с момента получения до принятия по ним процессуального решения;

- право на обжалование действий должностных лиц, ответственных за принятие процессуальных решений на данной стадии;

- наличие ответственности (как уголовной, так и иной) за неисполнение предписаний закона. 
На данной стадии возможны случаи нарушения процессуальных прав участников уголовного судопроизводства, связанные, в частности, с незаконным принятием органами предварительного следствия решения о возбуждении дела. Также нарушения в этой сфере зачастую обусловлены неполным объемом проверок по сообщениям о преступлениях, недостаточным исследованием сведений, имеющих существенное значение для объективной оценки признаков противоправного деяния.

Из-за большого количества нарушений на данной стадии уголовного процесса представляется необходимым предложить следующее. Нужно наделить прокурора функцией возбуждения уголовного дела в связи с отменой им постановления следователя, учитывая то, что руководители следственных органов - органов процессуального контроля - полномочны отменять незаконные постановления следователя об отказе в возбуждении дела.

По сути, незаконное постановление следователя является «совместным» документом следственного органа и органов ведомственного контроля (как прошедшее проверку), хотя прокурор и полномочен отменять постановления. Прокурорский надзор, являющийся независимым от ведомственных влияний, должен устранять нарушения радикально, посредством возбуждения дела, а не только заниматься отменой незаконных постановлений следователя, обращая внимание органов следствия на нарушения [3, с. 8].

Таким образом, мы не говорим о совмещении прокурором полномочий органа административной юрисдикции, когда им возбуждается производство об административном правонарушении, и функции надзора и следствия, когда он отменяет постановление следователя о возбуждении уголовного дела, которое прошло процедуру ведомственного контроля. В случае наделения прокурора полномочиями по возбуждению уголовного дела в связи с отменой необоснованного постановления их следует рассматривать не только как действенное процессуальное полномочие, которое выступает, во-первых, как средство действенного устранения нарушений, во-вторых, как предупредительная мера повышения ответственности следователя и руководителя следственного органа, в-третьих, как совмещение функций надзора и следствия.

Как отмечается в научной литературе по юриспруденции, ежегодно отменяются около $40 \%$ процессуальных решений дознавателей и следователей об отказе в возбуждении уголовных дел, в том числе неоднократно, как противоречащие закону. Здесь уже говорится о нарушении конституционных прав участников досудебного уголовного судопроизводства. В 2012 г. в более $11 \mathrm{mлн} \mathrm{случаев} \mathrm{такие} \mathrm{решения} \mathrm{были} \mathrm{отменены,} \mathrm{а} \mathrm{это} \mathrm{равнозначно} \mathrm{затратам} \mathrm{труда} \mathrm{порядка}$ 30 тыс. сотрудников органов расследования, которые нигде не учитываются на уровне государства [4, с. 9]. Следовательно, и с позиции затрат фредерального бюджета такая деятельность недейственна, что является еще одним аргументом в пользу оптимизации полномочий прокурора в стадии возбуждения уголовных дел.

Необходимо отметить, что законодатель не закрепил в УПК РФ количество допустимых отмен необоснованных постановлений и их сроки. Поэтому требуется более четкое правовое регулирование данного вопроса, дабы исключить в дальнейшем неограниченное использование рассматриваемой меры на усмотрение должностных лиц.

Базовые принципы уголовно-процессуального законодательства не предполагают множественной отмены прокурором вынесенного постановления об отказе в возбуждении уголовного дела по одним и тем же основаниям в целях дополнительной проверки сообщения о правонарушении.

Во-первых, отмена руководителями ведомственного контроля необоснованных постановлений следователя происходит по причине необеспечения полноты проверки; во-вторых, законодатель наделил должностных лиц полномочиями по отмене постановлений органа предварительного расследования (ч. 6 ст. 148 УПК РФ), поскольку допускает, что эти и иные постановления могут быть необоснованны. Естественно, дополнительная проверка не выступает как цель отмены, скорее это способ достижения цели.

То, что отмена таких решений по одним и тем же основаниям недопустима, не исключает их отмену по иным основаниям. Когда следственным органом не учтены все требования, учтенные в предыдущем постановлении об отмене процессуального решения, процесс отмены по одним и тем же основаниям становится вынужденным.

Необходимой гарантией защиты прав лиц в стадии возбуждения уголовного дела становятся установление жестких сроков, которые допускают отмену процессуальных решений с возобновлением проверки по сообщению о преступлении; соблюдение этих сроков; принятие обоснованных решений. Нормативный акт должен содержать нормы, согласно которым органы ведомственного процессуального контроля могут совершить отмену необоснованных решений, в том числе не один раз, в пределах 30 суток - максимальный срок проверки сообщения о преступлении. 
Материалы для проверки по истечении указанных сроков должны быть незамедлительно предоставлены прокурору. При этом дополнительной гарантией защиты прав участников процессуальной проверки сообщения о преступлении (безвестном исчезновении) будет служить наделение прокурора полномочиями по возбуждению уголовного дела в связи с отменой состоявшегося процессуального решения. В данной ситуации будет решена проблема сроков предоставления не только постановления, но и материалов проверки (ч. 4 ст. 148 УПК РФ).

Учитывая изложенное, целесообразно исключить из УПК РФ правило, согласно которому прокурору предоставляется право отмены постановления следователя, руководителя следственного органа о приостановлении предварительного следствия или о прекращении уголовного дела лишь в срок не позднее 14 суток с момента получения материалов по уголовному делу. Жалоба или иная информация может поступить к прокурору спустя две недели, и такое правило является абсурдным. При этом у руководителей следственных органов данное полномочие не зависит ни от каких сроков.

Таким образом, в статье определено значение прокурорского надзора для обеспечения процессуальных гарантий прав участников уголовного процесса. Особое внимание уделено стадии возбуждения уголовного дела как наиболее проблематичной.

По нашему мнению, уголовно-процессуальное законодательство давно требует изменений. В частности, необходимой гарантией защиты прав лиц в стадии возбуждения уголовного дела, на наш взгляд, должно стать установление жестких сроков, которые допускают отмену процессуальных решений с возобновлением проверки по сообщению о преступлении; их соблюдение; принятие обоснованных решений. Предложенные изменения преследуют главную цель формирование правовых условий для надлежащего обеспечения процессуальных гарантий прав участников уголовного процесса.

\section{Ссылки:}

1. Божьев В.П., Брусницын Л.В., Буланова Н.В. Энциклопедия Академии Генеральной прокуратуры Российской Федерации / под общ. ред. О.С. Капинус. М., 2013. С. 139-176.

2. Уголовно-процессуальный кодекс Российской Федерации от 18 дек. 2001 г. № 174-Ф3 : в ред. от 1 сент. 2016 г. // Российская газета. 2001. 22 дек.

3. Синельщиков Ю.П. Перспективы развития законодательства о прокуратуре в сфере досудебного уголовного процесса // Законность. 2015. № 10. С. 6-9.

4. Гаврилов Б.Я. Современные проблемы досудебного производства и меры по их разрешению // Российский следователь. 2013. № 21. С. 5-11.

\section{References:}

Bozhiev, VP, Brusnitsyn, LV, Bulanova, NV \& Kapinus, OS (ed.) 2013, Encyclopedia of the Academy of the General Prosecutor's Office of the Russian Federation, Moscow, p. 139-176, (in Russian).

Gavrilov, BYa 2013, 'Modern problems of the pre-trial proceedings and measures to resolve them', Rossiyskiy sledovatel, no. 21, pp. 5-11, (in Russian).

Sinelshchikov, YuP 2015, 'Prospects for the development of legislation on the prosecutor's office in the field of the pre-trial criminal procedure', Zakonnost, no. 10, pp. 6-9, (in Russian). 